\title{
Estimation of the Bankruptcy Risk of the Companies in the BIST Construction Index
}

(Research Article)

BIST İnsaat Endeksinde Yer Alan Firmaların Iflas Riskinin Tahmin Edilmesi

Doi: 10.29023/alanyaakademik.648125

\section{Samuray KARACA}

University of Pamukkale, Denizli Turkey

samuraykaraca@hotmail.com

Orcid No: 0000-0001-7702-1545

\author{
Ahmet KARACA \\ University of Pamukkale, Denizli Turkey \\ ahmed_karaca@hotmail.com
}

Orcid No: 0000-0001-8556-7337

How to cite this article: Karaca, S. \& Karaca, A. (2020). Estimation of the Bankruptcy Risk of the Companies in the BIST Construction Index. Alanya Academic Review, 4(2), Sayfa No. 25-38.

\begin{tabular}{|c|c|}
\hline \multirow{3}{*}{$\begin{array}{l}\text { Keywords } \\
\text { Altman Z Model, } \\
\text { Probability of } \\
\text { Bankruptcy, } \\
\text { Borsa istanbul, } \\
\text { Construction Index }\end{array}$} & ABSTRACT \\
\hline & $\begin{array}{l}\text { In this study, it is aimed to measure the effects of the recent négative } \\
\text { developments in the Turkish Construction sector on the financial failures of } \\
\text { the companies in Borsa Istanbul Construction Index. This study is }\end{array}$ \\
\hline & $\begin{array}{l}\text { particularly important with regard to determining whether the concordat } \\
\text { announcements, which started especially in the 3rd quarter of } 2018 \text {, carry a } \\
\text { risk for the construction sector and ascertaining whether there have been } \\
\text { any warnings beforehand. }\end{array}$ \\
\hline $\begin{array}{l}\text { Received: } 18.11 .2019 \\
\text { Accepted: } 25.02 .2020\end{array}$ & $\begin{array}{l}\text { The financial statements of the companies in the construction sector in } 2010 \text { - } \\
2018 \text { period will be analyzed with the Altman } Z \text { score model to see if they } \\
\text { carry bankruptcy risk. In addition, by comparing the calculated } Z \text { scores } \\
\text { with the stock prices of stock certificates, the extent to which the } \\
\text { probabilities of bankruptcy are priced in the stock market will also be } \\
\text { measured. }\end{array}$ \\
\hline & $\begin{array}{l}\text { Predicting bankruptcy risk is vital for both firms and stakeholders. The } \\
\text { findings will contribute significantly to strategy determination for firms and } \\
\text { investors in this sector. On the other hand, the results will also guide } \\
\text { investors' stock preferences. }\end{array}$ \\
\hline
\end{tabular}

\section{INTRODUCTION}

Financial crises caused the concept of financial failure to come to the forefront. The 2008 global financial crisis, which was especially caused by the real estate sector in the US and which turned into a worldwide crisis by spreading to other countries, had negative effects on companies. This crisis threatened all business areas and showed that the survival of companies depends on the efficiency and productivity of their activities, otherwise they may go bankrupt. 
Since the recent economic problems have led to bankruptcy of many firms, researches on risk and bankruptcy have become the focus of interest for firms and their stakeholders (Aliakbari, 2009). Before confronting such a problem, the focus of stakeholders worldwide was to minimize risk. However, due to the latest developments, stakeholders have started to look for ways to predict these risks as bankruptcy that poses a risk to the economy affects the financial system.

In this study, effects of the negative developments experienced in the last periods of 2018 on the financial failures of the construction companies in BIST have been measured with the Altman Z-score model, which has a wide area of usage.

This study aims to predict bankruptcy of companies in Turkish construction sector by using Altman Z score model. Predicting financial risk is a power factor. It helps both companies and investors to make prudent and correct decisions. The Altman Z score model can help managers take precautions before the firm gets in trouble and find solutions before the situation gets worse. In addition, the model may also allow investors to avoid losses by withdrawing their money from firms that are inclined to bankruptcy (Thai, 2014: 197-207). Altman (1968) Z-score model is a model that helps investors to predict the bankruptcy risk of a particular firm. This score is based on 5 financial ratios: profitability, leverage, liquidity, activity and solvency. By applying discriminant analysis to the data obtained from these ratios, Altman managed to develop a model that increases the bankruptcy risk estimation of firms.

In this study, it is aimed to determine the probability of bankruptcy of construction companies dealt in Borsa Istanbul using Altman $\mathrm{Z}$ score model. In addition, exposing how the situation reverberates in the stock prices in the stock exchange, is determined as another objective. The study continues with the status of construction sector in Turkey and in the world, explanations of developments, explanation of financial failure, explanation of Altman model, literature, method, application and evaluation of findings after the introduction and it concludes with conclusion and evaluation chapter.

\section{DEVELOPMENTS in the CONSTRUCTION SECTOR in TURKEY and in the WORLD}

The construction sector, which generally takes on the role of leverage in the national economies by creating added value and employment, is of great importance. In recent years, construction includes not only the construction of a building or structures but also maintenance, repair and all kinds of operational activities. Although building production is the first thing comes to mind when it comes to construction production, it is also used in the meaning of the production of understandable and sustainable projects that are environmentally friendly, include social responsibility and directly related to social life and social structure (Ergül, 2007).

Globalization, which has become an even more effective factor in the past two decades, creates different social and economic impacts in different countries. The most important asset of this interaction is seen in the construction sector and its associated securities. When it is considered that Global Economic Crisis (GEK) in 2008 arose from the negative developments based on the construction and a number of sub-sectors associated with the sector, the importance of construction sector across Turkey and the world will be better understood (Dalkılıç and Aşkın, 2017). 
While urbanization increases with deceleration throughout the world, the construction sector of countries also continues to grow in the long run. However, concerns over global growth in the short run increase the risks on the construction sector worldwide. While protectionist trends in world trade abuse financial markets and economic decision-makers' trust, they may lead to suspension of decisions on construction expenditures, particularly housing. In addition to this, uncertainties and increasing short-term risks also cause the postponement of governments' infrastructure investments. As a result of these factors, although the global construction sector maintained its short-term growth trend by the end of 2018, it has a fragile view. In the medium-long term, it is seen that the construction sectors of developed and developing economies have differentiated performances. Growth in advanced economies in general is expected to remain below the pre-crisis period in the coming period with aging population, protective trends in global trade, declining productivity tendencies. Therefore, the high level of indebtedness in many developed economies increases the downside risks of the global construction sector (KPMG, 2019).

Moreover, along with the high level of indebtedness, the exit process of developed countries from the supportive monetary policies increases the costs of the current debt, it also appears to be another limiting factor for growth. This threatens the recovery in labor markets and limits the demand for the construction sector, especially for housing, with the difference in the expenditure trends of generation Y. The challenges faced by the construction sector in developed economies are evaluated to be structural as a result of the level of maturity reached by these economies. While the challenges in developing economies are attributed to more temporary factors, fragility in global commodity prices, volatility in financial markets and slower growth rates compared to developed countries with trade partners may limit the construction sectors of developing economies. In other words, although developing economies naturally have a high growth potential in construction sectors, short-term difficulties stemming from uncertainties and risks in developed economies can be encountered. (https://assets.kpmg/content/dam/kpmg/tr/pdf/2019/01/sektorel-bakis-2019insaat.pdf).

Our country is a developing country and therefore its needs are increasing. As in other countries, the main axis of development is inevitably "construction". The first step of dams, energy production facilities, roads, airports, urban spaces, factories, hospitals and all other life spaces and of all the infrastructure that can make these spaces livable is taken with "construction". A country that is determined to walk to the future with confidence will no doubt start this march with "construction".

When the contribution of other sectors providing input to the sector and continuing their activities in line with the developments in this sector is also considered, it is revealed that the share of the construction sector in the GNP is around 30 percent.

The construction sector creates demand for the goods and services produced by more than 200 sub- sectors that are also connected to itself and this widespread effect is the main indicator of the sector's quality of being "the locomotive of the economy".

According to the results of a research conducted in the UK, there are 23,000 pieces that concem 150 different occupations in an average new house. Given that no economic activity has such a direct or indirect impact, the indispensable value of the locomotive power of the sector for developing countries becomes clearer.

Government policies and international credit institutions' decisions that affect politics and economy have a direct impact on the development of the construction sector. The choice of 
the authority that makes the investment decision or finances it directly affects the companies operating in this field.

For Turkey's economy in which high rate - steady growth and the need for employment creation are higher than ever before, the construction sector has become more important than ever (https://intes.org.tr/wp- content/uploads/2018/11/SEKT\%C3\%96R-RAPORU.pdf).

As of 2017, the share of the construction sector in the global economy is 15 percent while in Turkey the rate is 9 percent. Construction sector is intensely lively in developing countries due to the growth momentum of the national economy and the impact of government policies and investment potentials. By 2025, the share of the construction sector in the total economy is estimated to reach 10 percent in developed countries and 17 percent in developing countries. If we look at the world, ongoing low interest rates and stable commodity prices in Asia Pacific and North America indicate that the construction sector will make a solid entrance into 2018. While growth and stability are envisaged for the US and Canada, the revenue allocated to large infrastructure projects and housing constructions may increase by 4 to 6 percent. In Latin America, the recession in the construction sector due to the project cancellations because of budget cuts and various corruption scandals, is expected to continue also in 2018. China will maintain its activity in the construction area by maintaining its acceleration in the same way with the growth rates that are called new normal (Sektorel Bakis - insaat - 2018).

In Europe as a whole, a general recession in the construction sector might be foreseen. Brexit is still causing uncertainty in many sectors across Europe as well as in the UK. The construction sector is one of the sectors that is most affected by uncertainty.

The Russian construction sector is expected to grow by 1.76 percent annually by 2020 . Construction of 500,000 housing units will be completed in line with the aim of the government to provide housing for middle- and low-income groups. The general tendency of the construction sector in Russia to recover is an important development for the Turkish companies, which are very strong in the Russian market. In addition to Russia, there are also important market opportunities in markets such as the Caucasus and Ukraine, which have so far increased with deferred demands.

The construction sector in Turkey; the construction, which has become one of the most important economic sectors in the country with the added value it has created by going through a dynamic period due to the intensity of housing and infrastructure projects, has increased its share to 30 percent by means of the sectors it affects indirectly, in addition to its share of 9 percent in GDP.

When we evaluate in general, we predict that the construction sector in Turkey and in the world will continue to grow in the coming years. Research shows that China will be the largest construction market in the world in 2020, followed by the US, India, Japan and Canada. While no significant change is expected in its market size ranking, significant changes are expected in the growth rate ranking of the construction sector. Between 20182020, the Middle East and Africa regions will surpass Asia Pacific in the growth rate of the construction sector. In addition to the slowing growth of China, large infrastructure investments in the Gulf countries also play an important role in this development. In 2020, the sector will have grown 67 percent compared to 2010.

On the other hand, there is an activation in the African market. The demand is rather for housing than infrastructure in the market, which Turkish contractors are also following 
carefully. insaat.pdf).

(https://assets.kpmg/content/dam/kpmg/tr/pdf/2018/01/sektorel-bakis-2018-

Construction Industry of Turkey; the construction sector is one of the leading sectors of the Turkish economy, which is in a struggle for development, by creating employment and increasing exportation. It supports 150 secondary sectors such as cement, ceramic, wood and glass industry. The Turkish construction sector, which is a labor-intensive sector and largely based on the national capital, affects the production and employment process, as it directly or indirectly concerns many sub-sectors and many professional branches attached to it. The construction sector, which has the characteristics of a leading sector with many sectors connected to it, also has the feature of absorbing unemployment thanks to its potential to create employment (Dalkılıç and Aşkın, 2017).

Between the years of 2005 and 2006, the construction sector achieved record growth of $9.3 \%$ and $18.5 \%$, respectively. The sector grew by $5.7 \%$ in 2007 and with the impact of the global economic crisis which first broke out with the mortgage problem in the USA in the last period of the same year and then came to a global state as from 2008 by gradually growing, the construction sector and economic growth came to a halt and even started to recess. The global economic crisis, which also affects the Turkish markets through the European Union (EU) countries, led to a recess in both the economy and the construction sector by causing a reduction in exportation, an interruption in foreign investments and a decrease in domestic savings. However, the impact of the crisis did not last long, and the construction sector was able to become the sector that benefits the economy most by growing rapidly in 2010 and 2011 with the decrease of the interest rates. The rise in the costs, the fact that housing demand was limited and the uncertainties in the world markets in 2012 put the sector and the economy back in the process of recovery. When we look at the linear trend curve of the construction sector between the years of 2004 and 2014, we can see that the sector could not achieve a stable growth trend. We can actually accept this situation as an indication of the fact that the economy is more affected by external factors (Çınar, 2018:27).

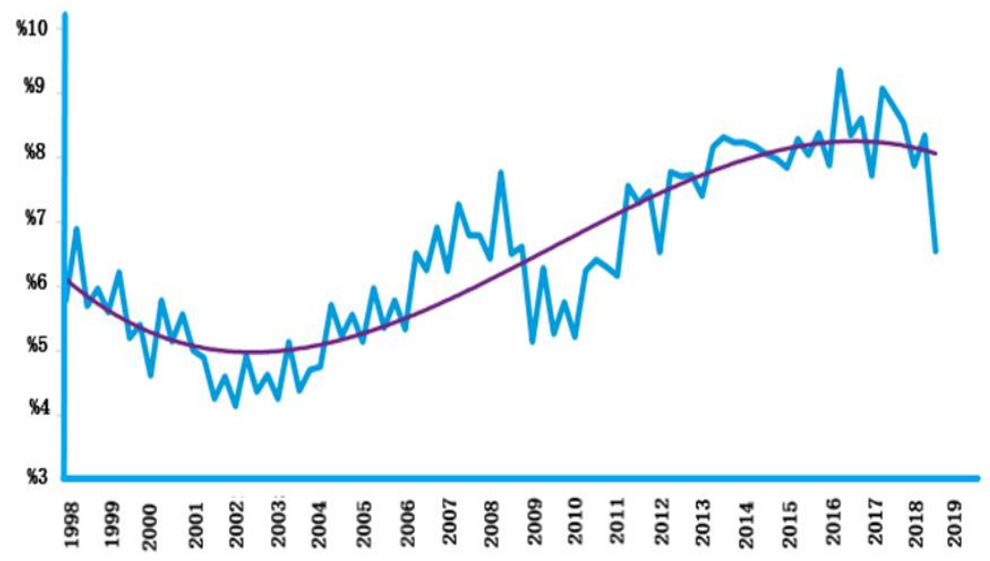

Reference: $T \ddot{I} I K$

Figure 1. Annual GDP and Construction Sector Growth Speeds

When we evaluate the relationship between the construction sector and economic growth since 2013, it is seen that the sector is in a stable development except for the decrease experienced in the second quarter of 2014. While 2013 was a year in which the sector 
increased above expectations, 2014 saw a depression in both economic and sectoral terms due to the increasing geopolitical risks and the upward movement of foreign exchange due to these risks. In 2015, Turkey's economy attained a growth rate of 6 percent and in this growth, the effects of private consumption and public spending have been great. Along with the economic growth, the growth performance of the construction sector was 4.9 percent. In all the quarters of 2016, the construction sector grew above economic growth. The growth of the sector in the first two quarters of 2017 was 5.6 percent and 5.5 percent. The construction sector, which surpassed industrial growth with the highest growth rate of the last 3 years with 18.7 percent according to the results of the third quarter, increased its investments by 12 percent in the same period. Despite the positive picture in 2016 and 2017, the sector's expectations for 2018 are more cautious. While the sector increased housing production and house sales especially in the last two years, the slowing down of the destocking rate especially in the projects addressing high income level shows that the sector is approaching saturation point in this segment. If the supply-demand imbalance persists in 2018, the sector will lose its growth acceleration it attained in 2016 and 2017. In the third quarter of 2018, the construction sector contracted by 5.3 percent compared to the same period of 2017 and became one of the sectors that limited growth. When we look at the long-term trends of the Turkish construction sector, it has become one of the most sensitive sectors to the fluctuations in the general economy (KPMG, 2019).

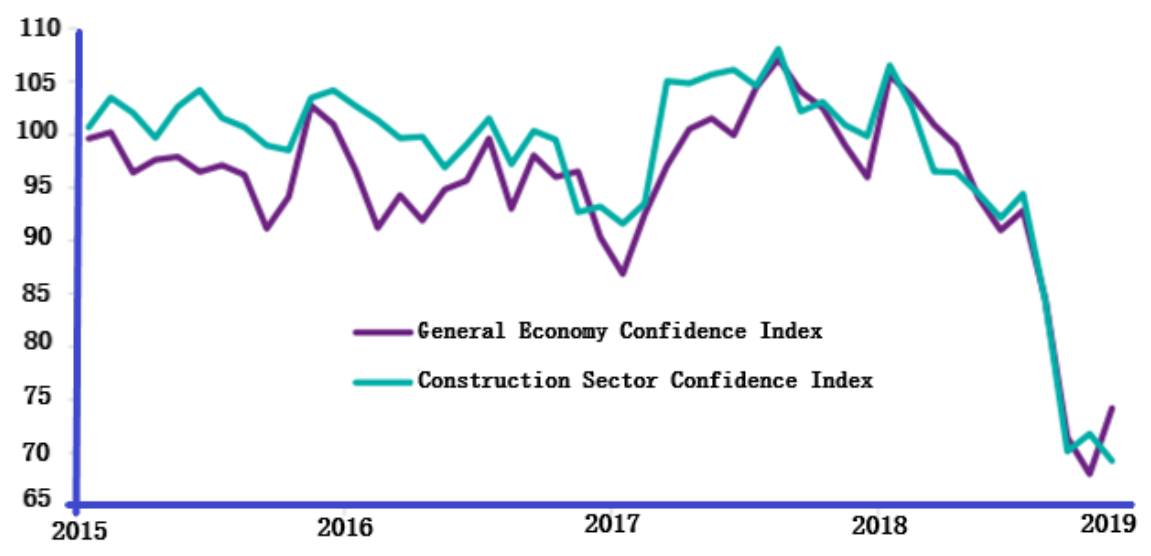

\section{Reference: $T \ddot{U} \dot{I} K$}

Figure 2. General Economy and the Construction Sector Confidence Index

According to the index data that are not purified from calendar and season effect, the confidence index in the construction sector completed 2016 with a significant downward trend. In the first 4 months of 2017, the confidence index increased and in March, it attained the biggest increase rate in the last two years with 12.3 percent. This increase, which can be interpreted with the positive predictions of entrepreneurs on employment due to the seasonal effect in the summer months, was -0.2 percent, 0.8 percent and 0.4 percent in April, May and June respectively, therefore, it was considered to be static. In November, it decreased by -2.2 percent compared to October. Overall, 2017 was a safer year compared to 2016. 


\section{FINANCIAL FAILURE}

Two types of financial failures are mentioned in the literature. These are; 1 - Technical failure (technical insolvency) and 2- Bankruptcy. Technical failure is defined as insufficient liquidity or in other words insufficient power to pay short-term debts of the company and inability to pay due debts (Gonenli, 1998: 600). The fact that an enterprise cannot pay its current debts indicates that this enterprise is technically unsuccessful (Dagli, 1994: 129). Bankruptcy is defined in many ways in many countries. In Turkey, bankruptcy is defined as that a company becomes unable to pay its debts (iiK,md.179) and in the UK it is defined as the status where payments are stopped and Altman defines bankruptcy as financial failure and he states that enterprises undergoing financial failure are legally bankrupt or enterprises that are given reorganization according to the provisions of bankruptcy (Altman, 1971: 3). The reasons for the bankruptcy can be stated as follows (Reen, 1990: 393-394):

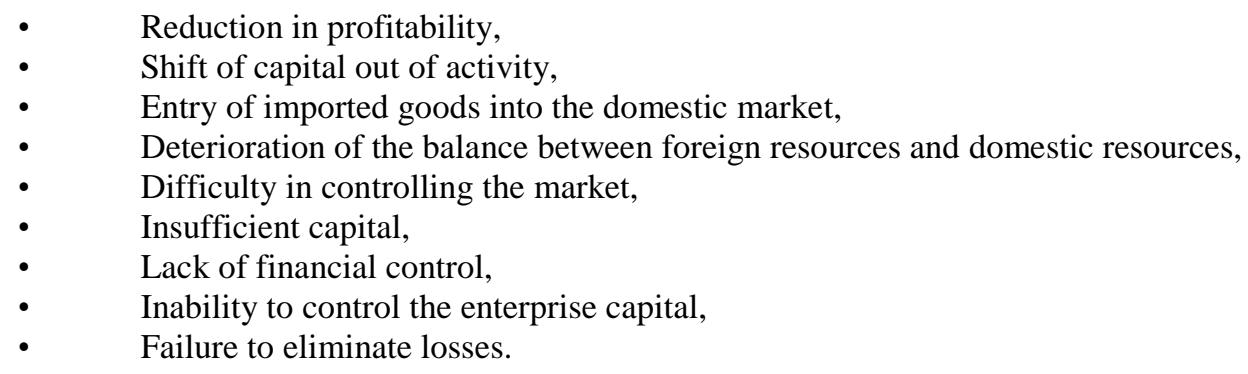

As it can be understood from the explanations above, financial failure is a process that starts with the failure of enterprises to pay their debts and ends with bankruptcy. There will surely be a risk of bankruptcy if payment difficulties last long.

The reasons for the failures within the enterprise are itemized below (Evin,

2014, p. 17):

Insufficient sales volume,

Too much increase in operational expenses,

Failure in management of debt receivable,

Low inventory turnover,

Excessive investment in tangible assets,

Incorrect selection of the establishment of the enterprise,

Lack of competitive advantage in the market,

Unprofessional management,

Strikes

receivables management, investment decisions and profit distribution policy cause financial failure (Orhan \& Abdullah, 2015, p. 26). In other words, errors in balance sheet management are the most important reasons for financial risk.

Another important factor that creates risk in companies is the environmental factor. Companies are in constant interaction with their environment. Economic, political and technological developments as uncontrollable environmental parameters affect the financial situation of the companies. Business managers should analyze the environment well and make their strategies accordingly. There are many environmental factors that develop beyond the control of enterprises and affect the business in different ways.

These factors are listed below (Uzun, 2005, p. 159): 
Difficulty in adapting to changing world standards,

Wars in the world,

Natural disasters,

Rapid changes in exchange rates,

Inflation and interest rates, rapid rise in interest rates and the lack of long-term debt due to high inflation.

\section{METHODS for ESTIMATING FINANCIAL FAILURE and ALTMAN MODEL}

It is very important that financial failure is foreseen in order to protect the company and its stakeholders and to maintain profitability by revealing the reasons for failure of the enterprises (Bartol and Nartin, 1991: 223 224 ). It is stakeholders, as well as the firm, that are most affected by financial failure and its possible negative effects. Lenders cannot take back the loan they have given, employees are at risk of losing their jobs. The financial failure prediction early warning system is an important model for making decisions about enterprises and evaluating businesses by providing independent and real information to the manager.

Using financial statements, Altman identified 22 financial ratios with potential importance and categorized them for evaluation. The ratios discussed in five categories are liquidity, profitability, leverage, debt repayment and efficiency. These ratios were chosen according to their relationship with the study and their popularity in the literature. In the Altman model, when successful and unsuccessful enterprises dependent variable is determined, the coefficients that determine the importance of the ratios used in the distinction of these enterprises are modelled as follows. In this model, the $\mathrm{Z}$ value on the left side of the equation shows the survival power of the companies, while the variables on the right of the equation represent the ratios and coefficients. The $\mathrm{Z}$ value is the sum of the coefficients multiplied by the ratios. The mathematical équation of the Altman model is as follows (Altman, 1968):

$$
\begin{aligned}
& \mathrm{Z}=1.2 \mathrm{X} 1+1.4 \mathrm{X} 2+3.3 \mathrm{X} 3+0.6 \mathrm{X} 4+0.999 \mathrm{X} 5 \\
& \mathrm{X} 1=\text { Working Capital/Total Assets; } \\
& \mathrm{X} 2=\text { Undistributed Earnings/Total Assets; } \\
& \mathrm{X} 3=\text { EBIT/ Total Assets; } \\
& \mathrm{X} 4=\text { Total Stock Value } / \text { Book Value of Liabilities; } \\
& \mathrm{X} 5=\text { Sales/ Total Assets; }
\end{aligned}
$$

Since the original Z-Score model is based on a firm's market value, it can only be applied to public companies. Altman (1983) emphasized that the Z-Score model was designed to be open to the public. The interpretation of the model in question is as follows:

- $\quad$ Companies with a $\mathrm{Z}$ value less than $1.81(\mathrm{Z}<1.81)$ have a high risk of bankruptcy.

- $\quad$ Companies with a $\mathrm{Z}$ value of $1.81<\mathrm{Z}<2.99$ are located in the gray area.

- $\quad$ Companies with a $Z$ value more than $2.99(Z>2.99)$ have a very low possibility of bankruptcy.

In 1983, Altman revised the first model developed in 1968 and created a new model with different coefficients for private enterprises.

$\mathrm{Z}=0.717(\mathrm{X} 1)+0.847(\mathrm{X} 2)+3.107(\mathrm{X} 3)+0.420(\mathrm{X} 4)+0.998(\mathrm{X} 5)$

Critical limits for private businesses are:

- Companies with a $\mathrm{Z}$ value less than $1.23(\mathrm{Z}<1.23)$ have a high risk of bankruptcy.

- Companies with a $\mathrm{Z}$ value of $1.23<\mathrm{Z}<2.99$ are located in the gray area. 
- Companies with a $Z$ value more than $2.99(Z>2.99)$ have a very low possibility of bankruptcy.

X1 - Working capital / Total assets

Working capital / Total Assets ratio; It is a financial ratio that measures the liquidity of a firm. Working capital is the difference between Current Assets and Short-Term Liabilities. If this difference is negative, the solvency is reduced. If it is positive, the risk of non-payment of debts is reduced. Therefore, this ratio is high in successful firms, while it is low in unsuccessful firms, and it is positively related to the financial health of a firm (Altman, 1968).

X2 - Undistributed profits / Total Assets.

Although this ratio is a measure of total profitability, it can also be said to be related to the age of the firm. The reason for this is opinions asserting that a young firm does not have enough time to grow and increase its overall profitability. Therefore, this ratio may be relatively low in young firms. It can be argued that the probability of bankruptcy of young firms in this distinctive process will be higher compared to the firms that are in the market for a long time. However, a company is more likely to fail and go bankrupt in its early years.

X3 - Profit before interest and taxes / Total assets.

The total EBIT / Assets ratio can be seen as an indicator of how effectively a company uses its assets. At the same time, this ratio is a measure of the firm's productivity. It can be said that the higher this ratio is, the higher a company's earnings are compared to its assets and the lower the financial distress is. This ratio is low in financially troubled firms.

X4 - Market Value of Equity / Total Liabilities.

This ratio is a measure of a company's financial leverage and the balance between equity and foreign resource. It also consists of two variables, one is the market value of equity and the other is the company's liabilities. Apart from financing, this structure provides a firm with a higher winning potential compared to others. In addition, it shows how much the value of assets can fall and go into bankruptcy when a company's debt exceeds its assets (Altman, 1968).

X5 - Sales / Total Assets.

The Net Sales / Total Assets ratio is an indication of the asset's ability to earn and how effectively it is used. This ratio, which represents the earning power of each TL invested in assets, increases as the utilization efficiency of the assets increases, while the decrease in sales for firms experiencing financial difficulties will result in a low result.

\section{LITERATURE}

Académie researchers around the world have used a variety of techniques and methods to estimate and assess bankruptcy risk. The most popular methods are the multiple discriminant method (Altman, 1968) and logit analysis (Ohlson, 1980). There are many researches accepted as "the standard method of bankruptcy prediction" based on Altman Z score model (Altman et al. 1977), Deakin (1972), Edmister (1972), Blum (1974), Deakin (1977), van Frederikslust (1978), Bilderbeek (1979), Dombolena and Khoury (1980), Tafiler (1982), Micha (1984). Betts and Belhoul (1987), Gloubos and Grammatikos (1988), Declerc et al. (1991), Laitinen (1992), Lussier (1994), Altman et al. (1995). Another important contribution to bankruptcy prediction studies was provided by J. Ohlson (1980). J. Ohlson used logit 
analysis to obtain a bankruptcy prediction model using nine variables such as business size, liquidity, profitability and performance.

The most common feature of the Altman Z Score Model is the use of other forecasting models and country-specific data. Using the proportions in this model with multivariate discriminant analysis has improved the ability to predict. The application of the new data to American companies and other companies has improved the performance of the model. Kwak et al., (2005), Using the Multi-Criteria Linear Programming model, they applied 5 Altman variable and 9 Ohlson variable on bankrupt companies in the United States and compared with the control companies between 1992-1998 about 6 times. Multi-Criteria Linear Programming performed better than the original Altman model.

Aziz and Dar (2006) showed that the most widely used model in the 89 studies conducted between 1968 and 2003 is the multivariate model (Z-value) and logit analysis. Chung et al. (2008) examined various financial ratios of 10 financial companies that went bankrupt in New Zealand between 2006 and 2007 and found that and 4 out of the 5 financial ratios that Altman (1968) used predicted the bankruptcy risk of the enterprise much better than other financial ratios. The research shows that statistical techniques (especially MDA and Logit models) are the most commonly used models, that the AIES approach is relatively new and that the theoretical models are relatively few. While the predictive accuracy looks generally good in all models, it shows that AIES and theoretical models have a slightly better average predictive accuracy than statistical models. However, this superior performance measured is based on fewer studies. On the other hand, the consistently high predictive accuracy and low Type I and II error rates of the MDA and Logit models have been achieved in a relatively large number of studies (with smaller standard deviations). The study suggests that these models can generally provide the most reliable methods of bankruptcy estimation.

Çelik (2010), on the other hand, aimed to develop an early warning model in order to predict the failure of banks in advance in his study. In the study, various financial ratios of 36 privately-owned commercial banks were calculated, and the probability of financial failure of these banks was tried to be predicted 1 or 2 years in advance. In this study in which discriminant analysis and artificial neural network models were used, it was found that the discriminant model could predict financial failure with $91 \%$ success rate 1 or 2 years in advance, and that the artificial neural network model could predict financial failure with $100 \%$ success rate 1 year before and with $88 \%$ success rate 2 years in advance.

The analysis that Zeytinoglu and Akarım (2013) performed based on 20 financial ratios and Altman's successful / unsuccessful distinction with the 2009, 2011 and 2012 data of the Istanbul Stock Exchange enterprises gave explanatory results with more than $88 \%$ rate in predicting the financial failure of the enterprises.

Sestayo, Gonzalez and Bua (2016) measured the financial success of accommodation businesses in Spain using probit and logit models. The financial data of 682 small and medium-sized enterprises selected as the sample were used for the years 2008-2011. At the end of the study, it was emphasized that the models used were successful in measuring financial failure, but that sector specific models should be developed.

Jawabreh, Rawashdeh and Senjelawi (2017) measured the financial failures of accommodation establishments in Jordan with the help of Altman Z Score. For this purpose, the data of the 13 accommodation companies in the Amman Stock Exchange for the years 2008-2009 were subjected to Altman Z score. As a result of the study, it was concluded that the financial failures of the companies could be estimated one year in advance. 
In their study, Karaca and Ozen (2017) examined the effect of recent developments in Turkey's tourism sector on the financial failure of the tourism businesses in the Istanbul Stock Exchange. Using the financial statements of the enterprises, it was measured whether they carried a bankruptcy risk by using Altman Z Score with the help of data between 2009-2016. At the same time, the prices of the companies' stocks were compared with the calculated ZScore and the amount of the price change was measured. As a result of the study, it was found that the problems caused by the crisis that was experienced in 2015-2016 between Turkey and Russia due to shooting down of a Russian fighter jet by Turkey increased the bankruptcy risk of tourism businesses. In addition, no significant change was observed in the stock prices of the enterprises during this period. As a result of the regression analysis, it was determined that the effect of the probability of bankruptcy on prices was not significant.

Merkevicius et al. (2006)have developed a hybrid artificial discriminant model that combines MDA and uncontrolled learning artificial neural network using firm data from the United States and Lithuania. This hybrid model has reached a high prediction power of $92.35 \%$. Xu and Zhang (2009) tested Altman's Z-score, Ohlson's O-score, and Merton's D-score models in Japanese firms to test whether these models were useful for predicting bankruptcy in Japan. They also combined these models into a new $\mathrm{C}$-score model. They developed the $\mathrm{C}$-score model using Japan-specific variables to check whether the institutional structure variables had any effect on the probability of bankruptcy.

Tinoco and Wilson (2013) used the original Z-score as a criterion for evaluating the performances of models combining macroeconomic, market and accounting information for UK firms. While the Altman Z-score model offers very high classification accuracy for firms experiencing financial difficulties $(87 \%)$, it is not possible to say the same thing when it comes to successful firms. Zhdanov (2013) developed the predictive power of three other models (Altman Z-score, Zmijewski's and Shumway's models) with another modification, which was introduced by him and which questions the inclusion of variables related to investment opportunities.

Reisz and Perlich (2007) developed a model of prevention options in bankruptcy prediction and compared their distinctive strength with other accounting and market-based models. The data set covers approximately 6,000 industrial firms from 1988 to 2002. The authors documented the superiority of Altman's Z- score model and other Z-score models for predicting short-term (1 year) bankruptcy. The model of prevention options for medium- and long-term bankruptcy prediction performed better than other models.

Pindado et al. (2008) developed a preliminary model to estimate the probability of financial distress (FDL) using a panel data methodology and presented a definition of financial distress. Their sample includes 1,583 US companies and 2,250 companies in G7 countries (1990-2002). They used the Z-score as a comparison in re-estimation. The FDL model outperformed the Z-score model in terms of stability and grading power for different countries and periods. In the case of re-estimation, only profitability and past-year profits remained important for different periods and countries in the Z-score model.

$\mathrm{Wu}$ et al. (2010) evaluated the performance of 5 models (Altman, 1968; Ohlson, 1980; Zmijewski, 1984; Shumway, 2001; Hillegeist et al., 2004) using a current data set for registered companies in the United States. Based on these models, the authors built their own integrated model, the multi-term logit model with an extended set of variables. The integrated model, which combines accounting and market data as well as firm characteristics, outperformed other models. 
Acosta-Gonzalez and Fernandez-Rodriguez (2014) used the Schwarz Information Critical Genetic Algorithms (GASIC) for variable selection along with the logit model for estimating bankruptcy. Altman's Z- score model was used as one of the two criteria for the authors' model evaluation. It performs better in predicting failing firms when it comes to predicting one step ahead, but error is high in predicting two and three steps ahead. For unsuccessful firms the performances of the models are similar in predicting two-three steps ahead, but for successful firms, the Altman model has poor predictive accuracy. The GASIC model performed better in predicting four steps ahead for unsuccessful firms, but similar results were achieved for successful firms.

The Z-score model developed by Altman serves as a unique guide for forecasting, handling and preventing bankruptcy for private and public manufacturing and non-manufacturing firms. There is evidence that the $\mathrm{Z}$ score model is better in competitive markets.

The $\mathrm{Z}$ score for bankruptcy prediction is a powerful diagnostic tool that predicts the likelihood of a company entering the bankruptcy process. Studies measuring the effectiveness of the $\mathrm{Z}$ score have shown a reliability of 70\% - 80\%.(Altman, et al., 2014; Taffler, 2011). The $\mathrm{Z}$ score model shows an accuracy of $95 \%$ using the MDA method (Ohlson, 1980).

In his study, Kulali (2016) used the financial statement data of the companies traded on Borsa Istanbul (BIST) between 2000 and 2013 for the last 2 years before bankruptcy and showed that the companies signaled bankruptcy according to Altman Z score. Türk and Kürklü (2017) determined whether 166 BIST companies experienced financial difficulties during the 20142016 period with the Altman $\mathrm{Z}$ model. The authors found that $69 \%$ of the companies in the study did not experience financial difficulties with the Altman model.

In most of the literature studies, calculation of bankruptcy probabilities of companies and their degree of realization were investigated. In this study, it is aimed to calculate the probability of bankruptcy of tourism companies listed in BIST and to determine the relationship between these possibilities and market values of the companies.

\section{METHOD}

In this study, $\mathrm{Z}$ scores were calculated by considering the enterprises in BIST Construction Index. 8- year balance sheet and income statement data between 2010-2018 of these companies were used and all financial statement data were taken from BIST and Public Disclosure Platform. The financial data of the enterprises have been included in the calculation annually since the year they went public. Since Borsa istanbul financial statements are announced in February-March, market values of the firms are calculated by taking the average of daily final quotations of January, February and March. Altman Z-Score model was used to determine whether the companies in the sector were financially successful or not. Altman's Z-Score model, which is accepted as the basic model in revealing the financial risk ratings of the firms, includes the analysis of the relationships between the five ratios by means of multi discriminant analysis in order to determine the bankruptcy risk of firms, and calculating a combined ratio according to their weights (Aksoy, 1993: 160). Altman Z-Score Model is as follows:

$$
\begin{aligned}
& \mathrm{Z}=1,2 \mathrm{~T} 1+1,4 \mathrm{~T} 2+3,3 \mathrm{~T} 3+0,6 \mathrm{~T} 4+0,999 \mathrm{~T} 5 \quad(8) \\
& \mathrm{T} 1-\text { Net Working Capital Assets Ratio }=\text { Net Working Capital } / \text { Total Assets } \\
& \text { T2 - Unallocated Profit Assets Ratio = Unallocated Profit } / \text { Total Assets } \\
& \text { T3- Total Assets Earnings Ratio = EBIT / Total Assets }
\end{aligned}
$$


T4- Financial ratio including market value $=$ Current Value of Equity / Book Value of Liabilities

T5 - Total Assets Turnover $=$ Net Sales $/$ Total Assets

In the next stage of the study, it was found out to what extent the $\mathrm{Z}$ scores of the companies, whose bankruptcy probabilities were calculated according to Altman $\mathrm{Z}$ model, explained the stock prices of the companies. Therefore, regression models were established to explain the stock price of each company in the study.

\section{FINDINGS}

Since the original Z-Score model is based on a firm's market value, it can only be applied to public companies. Altman (1983) emphasized that the Z-Score model was designed to be open to the public. The interpretation of the model in question is as follows:

- Companies with a $\mathrm{Z}$ value less than $1.81(\mathrm{Z}<1.81)$ have a high risk of bankruptcy.

- Companies with a $Z$ value of $1.81<Z<2.99$ are located in the gray area.

- Companies with a $Z$ value more than $2.99(Z>2.99)$ have a very low possibility of bankruptcy.

Table 1. Bist Construction Companies Z Score (Bankruptcy Risk)

\begin{tabular}{|r|r|r|r|r|r|r|r|r|r|}
\hline \multicolumn{1}{l|}{ COMPANIES } & ANELE & EDIP & ENKAI & KUYAS & ORGE & SANEL & TURGG & YAYLA & YYAPI \\
\hline YEARS & & & & & & & & & \\
\hline 2010 & 1.46 & 0.26 & 2.29 & & & & & & 9.03 \\
\hline 2011 & 1.57 & -1.24 & 2.4 & 1.54 & 2 & & & & 2.8 \\
\hline 2012 & 1.51 & 0.4 & 2.72 & 1 & 7.19 & 4.75 & & 1.58 & -0.64 \\
\hline 2014 & 1.17 & 0.1 & 2.89 & 1.01 & 1.57 & 4.61 & 1.93 & 2.44 & 0.08 \\
\hline 2015 & 1.19 & 0.64 & 3.1 & 1.66 & 1.79 & 3.65 & 4.29 & 1.53 & 0.6 \\
\hline 2016 & 1.39 & 0.52 & 3.29 & 1.15 & 3.19 & 3.66 & 4.39 & 0.23 & 0.13 \\
\hline 2017 & 2.49 & 0.46 & 3.54 & 0.43 & 3.86 & 1.69 & 5.41 & -0.01 & 1.15 \\
\hline 2018 & 2.25 & 0.45 & 3.25 & 0.34 & 4.05 & 2.27 & 4.02 & -0.05 & 0.83 \\
\hline & & & & & & & & & \\
\hline
\end{tabular}

When the $\mathrm{Z}$ score values of the companies included in the BIST Construction index from the 2010-2018 Financial Table data are examined, we can say that the $\mathrm{Z}$ scores of all companies except ORGE have decreased in 2018, in other words their risk of bankruptcy has increased, based on the original interpretation above. In parallel, it can be said that there is a significant decrease in the prices of companies traded on the stock exchange except ENKAI and SANEL. 
Table 2. Bist Construction Companies Stock Prices

\begin{tabular}{|l|l|l|l|l|l|l|l|l|l|}
\hline COMPANIES & ANELE & EDIP & ENKAI & KUYAS & ORGE & SANEL & TURGG & YAYLA & YYAPI \\
\hline YEARS & & & & & & & & & \\
\hline 2010 & 2.08 & 1.82 & 2.01 & & - & - & - & - & 1.92 \\
\hline 2011 & 1.8 & 1.35 & 2.07 & 1.4 & 0.68 & - & - & - & 1.7 \\
\hline 2012 & 1.8 & 1.34 & 2.48 & 1.42 & 5.1 & 2.73 & 23 & 3.96 & 0.89 \\
\hline 2013 & 0.83 & 0.81 & 3.41 & 2.1 & 0.8 & 3.14 & 17.12 & 3.87 & 0.67 \\
\hline 2014 & 1.12 & 0.89 & 3.13 & 1.86 & 0.72 & 4.03 & 35.02 & 3.77 & 1.3 \\
\hline 2015 & 0.99 & 0.77 & 3.27 & 3.28 & 1.39 & 1.92 & 39.02 & 1.94 & 0.76 \\
\hline 2016 & 1.6 & 0.93 & 4.44 & 3.03 & 2.72 & 1.98 & 35.75 & 1.29 & 1.08 \\
\hline 2017 & 3.39 & 1.12 & 4.81 & 4.18 & 3.68 & 2.05 & 39.23 & 1.97 & 1.09 \\
\hline 2018 & 1.82 & 0.67 & 4.84 & 1.53 & 3.49 & 2.32 & 29.22 & 0.91 & 0.27 \\
\hline
\end{tabular}

Table 3. Panel Data Regression Analysis Results

Cross-section random effects test equation:

Dependent Variable: F?

Method: Panel Least Squares

Date: 08/24/19 Time: 15:17

Sample: 20102018

Included observations: 9

Cross-sections included: 9

Total pool (unbalanced) observations: 72

\begin{tabular}{|c|c|c|c|c|}
\hline Variable & Coefficient & Std. Error & t-Statistic & Prob. \\
\hline $\mathrm{C}$ & 3.083396 & 0.520971 & 5.918551 & 0.0000 \\
\hline $\mathrm{Z} ?$ & 0.755167 & 0.214488 & 3.520790 & 0.0008 \\
\hline \multicolumn{5}{|c|}{ Effects Specification } \\
\hline \multicolumn{5}{|c|}{ Cross-section fixed (dummy variables) } \\
\hline R-squared & 0.938414 & Mean dependent var & & 4.637361 \\
\hline Adjusted R-squared & 0.929474 & S.D. dependent var & & 8.843396 \\
\hline S.E. of regression & 2.348524 & Akaike info criterion & & 4.673697 \\
\hline Sum squared resid & 341.9650 & Schwarz criterion & & 4.989901 \\
\hline Log likelihood & -158.2531 & Hannan-Quinn criter. & & 4.799579 \\
\hline F-statistic & 104.9683 & Durbin-Watson stat & & 1.455639 \\
\hline $\operatorname{Prob}($ F-statistic) & 0.000000 & & & \\
\hline
\end{tabular}

Table 3 shows the panel data régression analysis conducted to measure the relationship between companies' bankruptcy risk and stock prices by years. The stock price of the companies was taken as the dependent variable and Altman $\mathrm{z}$ score was considered as the independent variable.

When the $\mathrm{Z}$ score and stock prices of construction companies are generally compared as of 2018 , it is observed that the risk of bankruptcy increases while stock prices decrease. 
According to Table 3, no statistically significant relationship was found between $\mathrm{Z}$ score and stock price.

\section{CONCLUSION}

This study aims to reveal the effects of the crisis experienced in the last quarter of 2018 on the financial failures and stock prices of companies in the BIST construction sector. For this purpose, using the financial statements of the firms, Altman Z score between 2010-2018 was calculated. It was investigated how bankruptcy probabilities of firms were priced in Borsa Istanbul.

According to the results of the analysis, in the last quarter of 2018, increases in exchange rates, interest rates and inflation rates increased the bankruptcy risks of construction companies and negatively affected stock prices. However, a statically significant relationship in general could not be revealed at least in the short term.

The lack of data of some firms constitutes the boundaries of the research and this is due to the fact that the firms in question have begun their activities on BIST on recently. On the other hand, stock pricing is a very complex proces. Manipulative movements, different financial structures of firms, differences in purchasing behavior and decisions of investors, differences in forecasts, micro and macro developments affect bankruptcy probabilities and prices dissimilary.

This study can be repeated for othe longer-term sectors. There are many studies on the factors that affect the market value of stocks in the literature. It can be investigated whether the bankruptcy probability of firms is one of these factors.

\section{REFERENCES}

ACOSTA-GONZALEZ， E. \& FERNANDEZ-RODRIGUEZ， F. (2014), "Forecasting Financial Failure of Firms via Genetic Algorithms," Computational Economics, 43, pp. 133-157.

ALIAKBARI, S. (2009). Prediction of corporate bankruptcy for the UK firms in manufacturing industry. Brunel University.

AKSOY, A., (1993). İşletme Sermayesi Yönetimi, Gazi Büro Kitabevi, Ankara.

ALLAYANNIS, G., BROWN, G. W., \& KLAPPER, L. F. (2003). "Capital structure and financial risk: Evidence from foreign debtuse in East Asia”. Journal of Finance, 58(6), 2667-2709.

ALTMAN, E. I. (1968), "Financial Ratios, Discriminant Analysis and Prediction of Corporate Bankruptcy", Journal of Finance, 23(4), pp. 589-609.

ALTMAN, E. (1971). Bankruptcy in America, D.C. Heathand Company, Lexington.

ALTMAN, E. I. (2013). Predicting financial distress of companies: revisiting the Z-score and ZETA ${ }^{\circledR}$ models. In Handbook of research methods and applications in empirical finance. Edward Elgar Publishing.

ALTMAN, E. I. (2002). Bankruptcy, credit risk, and high yield junk bonds: a compendium of writings. Oxford: Blackwell Publishing. 
ALTMAN, E. I., DROZDOWSKA M. I., LAITINEN, E. K., \& SUVAS A. (2014). Distressed Firm and Bankruptcy Prediction in A International Context: A Review and Empirical Analysis of Altman's Z Score Model. Available at SSRN 2536340.

ALTMAN, E. I., DROZDOWSKA M. I., LAITINEN, E. K., \& SUVAS A. (2017). "Distressed Firm and Bankruptcy Prediction in A International Context: A Review and Empirical Analysis of Altman's Z Score Model”. Journal of International Financial Management \& Accounting, 28(2).

AZİZ, M. A., \& DAR, H. A. (2006). “Predicting corporate bankruptcy: where we stand?". Corporate Governance: The international journal of business in society.

BARTOL, K. K. \& NARTIN, C. D.(1991). Management. New York: McGraw-Hill Inc.

BLUM, M. P. (1974). "Failing company discriminant analysis". Journal of Accounting Research, 12 (1), 1-25.

ÇELIK, K. M. (2010). "Bankaların Finansal Başarısızlıklarının Geleneksel ve Yeni Yöntemlerle Öngörüsü”. Celal Bayar Üniversitesi Yönetim ve Ekonomi Dergisi, 17 (2), 129-143.

ÇELIK, Ş (2007) “Türk İnşaat Sektörü ve İnşaat Sektörünün Ülke Ekonomisine Etkilerinin Araştırılması”. Yüksek Lisans Tezi, Beykent Üniversitesi, Sosyal Bilimler Enstitüsü İşletme Yönetimi Ana Bilim Dalı, İstanbul

ÇINAR, M. C. (2018). “Türk İnşaat Sektörü ve Türk İnşaat Sektörünün Ülke Ekonomisine Etkileri”. Basılmamış Yüksek Lisans Tezi, Nevşehir Hacı Bektaş Veli Üniversitesi Sosyal Bilimler Enstitüsü, Nevşehir.

DAĞLI, H. (1994) “İşletme Başarısızlıkları ve Alınması Gerekli Önlemler”. Verimlilik Dergisi, MPM Yayınları, Sayı:1, Ankara.

DALKILIÇ B., AŞKIN, M. (2017). Gayrimenkul ve Konut Sektörüne Bakış (Eylül 2017). Emlakkonut GYO A.Ş.

DEAKIN, E. B. (1977). Business failure prediction: An empirical analysis. In E. Altman, \& A. Sametz (Eds.), Financial crises: Institutions and markets in a fragile environment. New York: John Wiley.

EDMISTER R. (1972). “An Empirical Test of Financial Ratio Analysis for Small Business Failure Prediction”. Journal of financial and quantitative analysis, 7(2), 1477-1493.

ERGÜL N. (2007). “İnşaat Sektöründe Globalleşmenin Etkileri”. Vergi Sorunları Dergisi, Say1: 227.

EVIN, K. (2014). İşletmelerde Finansal Risk Yönetimi Ve İmkb'de İşlem Gören Çimento Şirketine Yönelik Bir Uygulama, Yüksek Lisans Tezi, Okan Üniversitesi Sosyal Bilimler Enstitüsü İşletme Anabilim Dalı. İstanbul.

JAWABREH, O. A., AL RAWASHDEH, F. \& SENJELAWI, O. (2017). "Using Altman's ZScore model to predict the financial failure of hospitality companies-case of Jordan". International Journal of Information, Business and Management, 9(2), 141-157.

KARACA, S. \& ÖZEN, E. (2017). "Financial failure estimation of companies in BIST tourism index by Altman Model and its effect on market prices". BRAND. Broad Research in Accounting, Negotiation, and Distribution, 8(2), 11-23. 
GÖNENLİ, A. (1988). Finansal Yönetim, İstanbul Üniversitesi Yayınları, No: 3463, İstanbul. KPMG (2018). Sektörel Bakış (İnşaat). KPMG Bağımsız Denetim ve Serbest Muhasebeci Mali Müşavirlik A.Ş.

KULALI, İ. (2016). “Altman Z-Score Modelinin BİST Şirketlerinin Finansal Başarısızlık Riskinin Tahmin Edilmesinde Uygulanması". Uluslararası Yönetim İktisat ve İşletme Dergisi, 12(27), 283-292.

KWAK, W., SHI, Y., J.J. CHEH \& H. LEE. "Multiple Criteria Linear Programming DataMining Approach: An Application for Bankruptcy Prediction," Data Mining and Knowledge Management 3327 (2005), pp. 164-173.

MERKEVICIUS, E., GARŠVA, G., \& GIRDZIJAUSKAS, S. (2006, May). A hybrid SOMAltman model for bankruptcy prediction. In International Conference on Computational Science (pp. 364-371). Springer, Berlin, Heidelberg.

MEYER, N. \& MEYER, D. (2015). "The role and impact of tourism on local economic development: A comparative study". African Journal for Physical Health Education, Recreation and Dance, 21, 197-214.

OHLSON, J. (1980). "Financial ratios and probabilistic prediction of bankruptcy". Journal of Accounting Research, 18 (1), 109-131.

SELIMOĞLU, S., \& ORHAN, A. (2015). "Finansal Başarısızlığın Oran Analizi ve Diskriminant Analizi Kullanılarak Ölçümlenmesi: BIST'de İşlem Gören Dokuma, Giyim Eşyası ve Deri İşletmeleri Üzerine Bir Araştırma”. Journal of Accounting \& Finance.

PINDADO, J., RODRIGUES, L. \& C. de la TORRE. (2008). "Estimating Financial Distress Likeli-hood”. Journal of Business Research, 61, pp. 995-1003.

REEN, B. (1990). Finansal Analysis, Prentice Hall, U.K.

REISZ, A. S., \& PERLICH, C. (2007). "A market-based framework for bankruptcy prediction". Journal of financial stability, 3(2), 85-131.

LADO-SESTAYO, R., OTERO-GONZÁLEZ, L., VIVEL-BÚA, M., \& MARTORELLCUNILL, O. (2016). "Impact of location on profitability in the Spanish hotel sector". Tourism Management, 52, 405-415.

TAFFLER, C. (2011). “Alternative Financial Ratios as Predictors Of Failure”. Accounting Review, XLIII, 113-122.

THAI, S. B., GOH, H. H., HENGTEH, B., WONG, J.C. \& ONG T. S. (2014). “A Revisited of Altman Z- Score Model for Companies Listed in Bursa Malaysia". International Journal of Business and Social Science, 5 (12), 197-207.

TINOCO, M. \& N. WILSON, "Financial Distress and Bankruptcy Prediction AmongListed Companies Using Accounting, Market and Macroeconomic Variables". Inter-national Review of Financial Analysis, 30, (2013), pp. 394-419.

KÜRKLÜ, E., \& TÜRK, Z. (2017). "Financial Failure Estimate in BIST Companies with Altman (Z-Score) and Springate (S-Score) Models". Osmaniye Korkut Ata Üniversitesi İktisadi ve İdari Bilimler Fakültesi Dergisi, 1(1), 1-14. 
UZUN, E. (2005). “İşletmelerde Finansal Başarısılığın Teorik Olarak İrdelenmesi”. Muhasebe ve Finansman Dergisi, (27).

XU, M., \& ZHANG, C. (2009). "Bankruptcy prediction: the case of Japanese listed companies". Review of Accounting Studies, 14(4), 534-558.

WU, Y., GAUNT, C. and S. GRAY. (2010). "A Comparison of Alternative Bankruptcy PredictionModels". Journal of Contemporary Accounting and Economics, 6, pp. 3445.

ZEYTINOGLU, E.,\& AKARIM, Y. D. (2013). "Financial failure prediction using financial ratios: an empirical application on Istanbul Stock Exchange". Journal of Applied Finance \&Banking, 3(3), 107-116.

ZHANG, L., ALTMAN, E.I. and J. YEN. (2010). "Corporate Financial Distress Diagnosis Modeland Application in Credit Rating for Listing Firms in China". Frontiers of Computer Science in China, 4, pp. 220-236.

ZMIJEWSKI, M.E. (1984). "Methodological Issues Related to Estimation of Financial Distress Prediction Models". Journal of Accounting Research, 22(1), 59-82.

https://intes.org.tr/wp-content/uploads/2018/11/SEKT\%C3\%96R-RAPORU.pdf

https://assets.kpmg/content/dam/kpmg/tr/pdf/2018/01/sektorel-bakis-2018-insaat.pdf https://assets.kpmg/content/dam/kpmg/tr/pdf/2019/01/sektorel-bakis-2019-insaat.pdf www.mo.org.tr/belgedocs/BilgiNotuYapıAraştirmaDerneği.doc 